la agudeza - muy británica- de quien conoce a fondo la profesión. Aún más inquietante resulta el convencimiento de los autores de que esos extravíos son los que están detrás de los pobres resultados de tanta arquitectura prescindible. No cabe duda de que los que dicen que la crítica ha muerto aquí tienen quien les contradiga.

Advertencia al lector: si alguien se reconoce, se ofende o se siente maltratado, es que quizá tiene algo sobre lo que meditar seriamente. Eso sí, siempre puede regalarle el libro a su cónyuge, a quien seguro que sí divertirá.

Robert Adam, Louis Hellman Traducción: Isabel Suárez-Llanos Los siete pecados capitales de los arquitectos

Ediciones Asimétricas, 2020

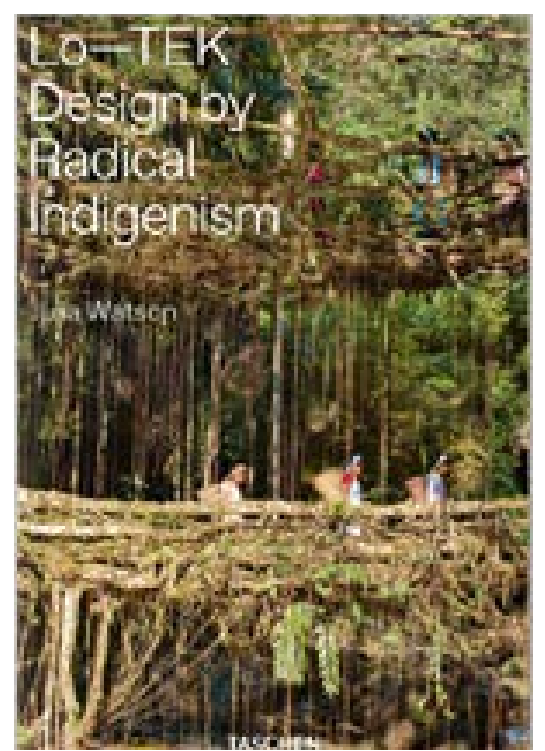

\section{Our Need for Traditional Ecological Knowledge}

\section{Los conocimientos ecológicos tradicionales que necesitamos \\ A nossa necessidade de conhecimento ecológico tradicional}

\section{Harriet Wennberg}

Lo-TEK's 419 pages are held together by an innovative binding that allows them to fall open at any point with equal ease. This edition has been designed to illustrate the fact that a traditional object (in this case, a book) can be state-of-the-art, echoing the content between the covers which demonstrates that indigenous cultures deserve not romanticised idealisation, but recognition for the highly advanced and adapted benefits they offer. Author Julia Watson's central argument is that the traditional ecological knowledge (TEK) of cultures and communities across the globe has answers to the climate crisis we face in the 21st century: the ancient and time-tested is the radical and current. It is an argument made not by arguing, but by amassing a compelling compendium of detailed examples of indigenous philosophy and vernacular architecture.

The book is divided geographically and ecologically into sections on mountains, forests, deserts, and wetlands. Each entry is dedicated to a particular practice, system, or technology and has a summarising introduction and conclusion along with more in-depth information, diagrams, photographs, and illustrations. Content ranges from the waru waru agricultural terraces of the Inca in Peru and the kihamba forest gardens of the Chagga in Tanzania, to the qanat underground aqueducts of Iran and the sawah tambak rice-fish aquaculture of the Javanese in Indonesia.

We have entered the decade of action towards the UN's 2030 Sustainable Development Goals. 2021 is being called "an environment super-year", and we need a global shift towards symbiosis with nature. In designing cities, and in facing the challenges of the climate crisis, Lo-TEK argues that we must acknowledge indigenous innovation and age-old ecological knowledge.

Watson'sthoroughresearch, meticulous compilation, and veneration for the subject matter will help her readers to develop more of a sense of awe for what humans are capable of, and to reflect on what actions they can take to live more in balance with nature. This book is needed. So too is all the knowledge referenced and contained between its covers. The critical thing is, of course, what happens next. Let us hope that the ways of the past are allowed to inform the ways of the future.

\section{Julia Watson}

Lo-TEK: Design by Radical Indigenism Taschen, 2019 